University of Nebraska - Lincoln

DigitalCommons@University of Nebraska - Lincoln

USDA National Wildlife Research Center - Staff Publications
U.S. Department of Agriculture: Animal and Plant Health Inspection Service

2000

\title{
Strychnine Alkaloid and Avian Reproduction: Effects Occur at Lower Dietary Concentrations with Mallard Ducks Than with Bobwhite Quail
}

\section{A. Pedersen}

Bic-Life Associates, Ltd., Neillsville, Wisconsin

R. T. Sterner

U.S. Department of Agriculture, National Wildlife Research Center

M. J. Goodall

U.S. Department of Agriculture, National Wildlife Research Center

Follow this and additional works at: https://digitalcommons.unl.edu/icwdm_usdanwrc

Part of the Environmental Sciences Commons

Pedersen, C. A.; Sterner, R. T.; and Goodall, M. J., "Strychnine Alkaloid and Avian Reproduction: Effects Occur at Lower Dietary Concentrations with Mallard Ducks Than with Bobwhite Quail" (2000). USDA National Wildlife Research Center - Staff Publications. 820.

https://digitalcommons.unl.edu/icwdm_usdanwrc/820

This Article is brought to you for free and open access by the U.S. Department of Agriculture: Animal and Plant Health Inspection Service at DigitalCommons@University of Nebraska - Lincoln. It has been accepted for inclusion in USDA National Wildlife Research Center - Staff Publications by an authorized administrator of DigitalCommons@University of Nebraska - Lincoln. 


\title{
Strychnine Alkaloid and Avian Reproduction: Effects Occur at Lower Dietary Concentrations with Mallard Ducks Than with Bobwhite Quail
}

\author{
C. A. Pedersen, ${ }^{1}$ R. T. Sterner, ${ }^{2}$ M. J. Goodall ${ }^{2}$ \\ ${ }^{1}$ Bio-Life Associates, Ltd., Neillswille, Wisconsin 54456, USA \\ ${ }^{2}$ U.S. Department of Agriculture, National Wildlife Research Center, 4101 LaPorte Avenue, Ft. Collins, Colorado 80521-2154, USA
}

Received: 1 March 1999/Accepted: 24 November 1999

\begin{abstract}
Separate subchronic reproductive toxicity studies were conducted using mallard ducks (Anas platyrhynchos) and northem bobwhite quail (Colinus virginianus). Three groups (32/group; 16 male-female pairs) of 17 -week-old ducks ( $F_{0}$ generation) were fed Purina ${ }^{(19}$ Game Bird Breeder Layena ${ }^{8}$ diets containing mean ( \pm SD) $33.2( \pm 2.7), 68.9( \pm 1.8)$, and 140.9 $( \pm 5.1) \mu \mathrm{g} / \mathrm{g}$ strychnine for 20 weeks, with some pairs in each group fed control diet during a subsequent 3-week recovery period. Three groups (32/group; 16 male-female pairs) of 19-week-old quail ( $F_{0}$ generation) were fed similar diets containing mean ( \pm SD) 279.2 ( \pm 10.1$), 557.4$ ( \pm 43.5 ), and $1,113.6( \pm 46.6) \mathrm{kg} / \mathrm{g}$ strychnine for 22 weeks without a recovery period. Separate groups of ducks and quail (32/group; 16 male-female pairs) were also fed control diets $(0.0 \mu \mathrm{g} / \mathrm{g}$ strychnine) in each study. There were 16 weekly collections of eggs for the mallard study (13 for the diet-exposure period and 3 for the recovery period), and 11 collections for the quail study. Eggs laid during the last 13 and 10 weeks of the diet-exposure periods for ducks (plus 3 weeks of the recovery period) and quail, respectively, were incubated. Each hatch of $F_{1}$ generation ducklings and chicks was observed for 14 days. Key results were: (1) the no observed adverse effect levels (NOAELs) for $F_{0}$ ducks and quail were 33.2 and $1,113.6 \mu \mathrm{g} / \mathrm{g}$ strychnine, respectively-quail showed no reproductive effects at the current doses; (2) decreased egg production and hatching success occurred for mallard hens fed mean $140.9 \mu \mathrm{g} / \mathrm{g}$ strychnine diets; and (3) "normal-hatching" ducklings from eggs of $F_{0}$ mallards fed mean $140.9 \mu \mathrm{g} / \mathrm{g}$ strychnine diets suffered greater mortality
\end{abstract}

Portions of these data were presented at the 15th Annual Meeting of the Society of Environmental Toxicology and Chemistry (SETAC), Oct. 30-Nov. 3, 1994, Denver, CO (Abstract 88, p 16, SETAC Abstract Book). The research was carried out while Sterner and Goodall were at the Denver Wildife Research Center (DWRC), Denver, CO; DWRC was closed on August 4, 1997. References to trade names and cormercial products do not imply endorsement by the federal government.

Correspondence to: R. T. Stemer than ducklings from the other diet groups. Possible mechanisms of strychnine action on avian reproduction are discussed.

Strychnine is a toxic derivative of seeds from Stryhnos nuxvomica plants and beans from $S$. ignatti plants (Merck Index 1996). It is an acute toxicant that blocks inhibitory motor pathways in the spinal cord (Murphy 1986); it remains one of the most widely used broad-spectrum pesticides in the world (Buck 1991). Median lethal doses $\left(L D_{50}\right)$ of strychnine for many mammalian and avian species are $<20 \mathrm{mg} / \mathrm{kg}$ (Gratz 1973; Hudson et al. 1984; USDA 1994).

In the United States, strychnine is registered only as a rodenticide (USDA 1994; Ramey et al. 1994). Concerns over primary and secondary hazards to nontarget avian species were a major factor in a 1983 injunction that halted above-ground applications of the poison in this country (Federal Register 1983). Though resolution of the injunction led to restricted-use registrations (i.e., below-ground, in-burrow placement of baits to mitigate nontarget exposure), much about the primary toxicity of strychnine in nontarget avian species remains unknown (see Colvin et al. 1988; Ramey et al. 1994). Many acute comparative studies have been performed (see Hudson et al. 1984; USDA 1994), but subchronic ( $>24 \mathrm{~h}$ ) and chronic $(>10 \%$ of life span) data on strychnine effects are rare.

Stemer et al. (1998) showed that subchronic dietary toxicity was much less pronounced in northern bobwhite quail (Colinus virginianus) than in mallard ducks (Anas platyrhynchos)findings in agreement with reported acute toxicities of 112-161 $\mathrm{mg} / \mathrm{kg}\left(\mathrm{LD}_{50}\right)$ for California quail (Callipepla californica) versus $2.27-5.88 \mathrm{mg} / \mathrm{kg} \mathrm{LD}_{50 \mathrm{~s}}$ for mallard ducks (Hudson et al. 1984; USDA 1994). Sterner ef al. (1998) reported 28-day (continuous exposure) no observed effect concentrations (NOECs) of $972.6( \pm 54.0)$ and $91.1( \pm 27.3) \mu \mathrm{g} / \mathrm{g}$ strychnine for adult quail and ducks, respectively-tenfold less sensitivity in the gallinaceous than the waterfowl species.

The current research sought to quantify reproductive toxicity 
induced by subchronic ( $>24 \mathrm{~h}$ but $<10 \%$ of life span; Brown 1988) dietary intake of strychnine in adult mallard ducks and bobwhite quail. Based on Sterner et al. (1998), weekly diets intended to contait 35,70 , and $140 \mu \mathrm{g} / \mathrm{g}$ and 300,600 , and $1,200 \mu \mathrm{g} / \mathrm{g}$ strychnine alkaloid were fed to adult mallards and bobwhites for 20 and 22 weeks, respectively. Numerous clinical sign, body weight, diet consumption, egg production, hatching, survivability/mortality, and gross pathology variables were then measured in the $F_{0}$ and $F_{1}$ generation birds.

\section{Materials and Methods}

Detailed technical product, diet preparation, and diet analysis information is provided in Stemer et al. (1998). The live-bird and dietpreparation portions of the studies were conducted at Bio-Life Associates, Ltd,; diet analyses were performed at the Denver Wildlife Research Center (DWRC).

\section{Strychnine Alkaloid}

The strychnine alkaloid (CAS \#57-24-9; $\mathrm{C}_{23} \mathrm{H}_{22} \mathrm{~N}_{2} \mathrm{O}_{3 ;}$ Lot $0910003082-\mathrm{UN}$ 1692) was manufactured by DECCAN Phytochemicals (PTadesh, India); it was obtained through Nott Manufacturing $\mathrm{Co}_{n}$, Inc. (Pleasant Valley, NY) via Pocatello Supply Depot (Pocatello, ID). Chemical assays of the technical product consistently indicated a mean purity of $\geq 99.3 \%$ active ingredient.

\section{Ducks and Quail}

Adult 14-week-old mallard ducks and 15-week-old northem bobwhite quail were purchased from Whistling Wings, Inc. (Hanover, IL) and Oak Ridge Game Farm (Gravette, AR), respectively. The birds were phenotypically indistinguishable from wild mallards and bobwhites. Nineteen- and 32-day quarantine periods preceded the duck and quail studies, respectively.

A total of 128 (64 males and 64 females) ducks and quail each were selected randomly from shipments of 144 ( 72 males and 72 females) ducks and 142 ( 71 males and 71 females) quail. Ducks and quail were assigned randomly to pairs; all pairs were housed in separate wire cages. Minimum-maximum mean $( \pm S D$ ) body weights of male and female mallards assigned to diet groups were $1,173.5$ ( \pm 104.3 )$1,184.9( \pm 86.1) \mathrm{g}$ and $1,046.4( \pm 89.9)-1,062.9( \pm 114.2) \mathrm{g}$, respectively. Minimum-maximum mean ( \pm SD) body weights of male and female bobwhites assigned to diet groups were $204.8( \pm 13.7)-208.6$ $( \pm 15.4) \mathrm{g}$ and $196.8( \pm 14.6)-204.5( \pm 16.9) \mathrm{g}$, respectively.

Duck cages $\left(61 \times 122 \times 61 \mathrm{~cm} ; 2.54-\mathrm{cm}^{2}\right.$ wire mesh) were located in a room with mean daily temperature and relative humidity (RH) of $19^{\circ} \mathrm{C}$ (min-max $15-36^{\circ} \mathrm{C}$ ) and $72 \%$ (min-max 56-95\%) for the 20-week test period and $21^{\circ} \mathrm{C}$ (min-max $16-29^{\circ} \mathrm{C}$ ) and $86 \%$ (min-max $70-95 \%$ ) for the 3-week recovery period, respectively. Quail cages $\left(53 \times 61 \times 38 \mathrm{~cm} ; 2.54-\mathrm{cm}^{2}\right.$ wire mesh) were located in a room with mean daily temperature and $\mathrm{RH}$ of $23^{\circ} \mathrm{C}\left(\min -\max 18-30^{\circ} \mathrm{C}\right)$ and $59 \%$ (min-max 41-86\%) for the 22-week test period (no recovery period) (Note-The ranges of temperatures and RHs during the duck and quail studies involved a few extreme readings for $1-2$ days of the test periods; otherwise, data were much less dispersed.)

For both species, diets were presented ad libitum using metal feeders attached to the side of each cage. Ad Ibitum water was provided to the ducks via an automatic, tube-dispenser system in each cage; ad ibitum water was provided to the quail via a 1.2-L plastic jar found attached to each cage (Kubl Corp., Flemington, NJ).

\section{Diet Preparations and Analyses}

Diet Prepurations: Control diets (0 $\mu \mathrm{g} / \mathrm{g}$ strychnine) were mixed as 2 parts propylene glycol:98 parts Purina Game Bird Breeder Layena (Purina Mills, St. Lonis, MO) by weight. Test diels contained 2 parts propylene glycol-strychnine:98 parts Purinde Game Bird Breeder Layena ${ }^{\text {बi }}$ by weight.

Test diets for the duck groups were intended to contain $0,35,70$, and $140 \mu \mathrm{g} / \mathrm{g}$ strychnine (nominal); the test diets fed to the quail groups were intended to contain $0,300,600$, and $1,200 \mu \mathrm{g} / \mathrm{g}$ strychnine. For ducks, $36-\mathrm{kg}$ batches of the diets were made during the first 12 weeks, but $45 \mathrm{~kg}$ batches were required thereafter due to the greater energy demands of this species during egy production. For quail, $20-\mathrm{kg}$ weekly batches of diet were prepared throughout the study.

Diet Untfomity: The uniformicy of diets was monitored monthly Dual, $-50-\mathrm{g}$ and $-250-\mathrm{g}$ samples of test and control diets, respectively, were collected from weekly batches and stored frozen. Samples from weeks (batches) $1,5,9,13,17$, and 20 were then analyzed using Analytical Method 25A (Furcolow 1990). Samples from remaining batches were stored frozen; these were analyzed only if strychnine determinations for the samples exceeded $\pm 15 \%$ of the nominal value. In these cases, the preceding and following week's samples for respective diets were also analyzed; this was a check for the anomalous or repeated occurrence of errors in the mixing of diets.

\section{Procedures}

The study designs were similar; both the duck and quail designs involved three strychnine-diet groups and a control group, respectively (Figure 1). The main difference between the designs was the inclusion of a 3 -week recovery period for the mallatd ducks, with additional necropsy of four pairs of ducks performed before and after this period.

Each study evaluated 21 variables of strychnine-induced effects in $F_{0}$ and $F_{\mathrm{l}}$ generation ducks and quail, plus standard clinical sign observations and necropsy examinations. Specifically, these were: $2 F_{00}$ generation duck and quail growth and maintenance variables (i.e., g body weight and estimated $g$ diet consumption); $14 F_{0}$ generation duck or quail egg production, embryo, and hatching variables (i.e., eggs laid, eggshell thickness, nomal eggs laid per hen, $\%$ normal eggs, $\%$ abnormal eggs, \% cracked/broken eggs, $\%$ defective eggs, $\%$ infertile eggs, $\%$ viable embryos of set, \% embryo mortalities at 1 week of set. \% embryo mortalities at midterm of set, $\%$ live embryos at 21 days [duck] or 17 days [quail] of set, $\%$ embryo montalities at full tem of set, and \% pipped but unliberated hatchlings); and $6 \mathrm{~F}_{1}$ generation duckling/chick growth and survival variables (i.e., \% nomnal hatchlings of set, \% day-14 survivors of set, \% normal hatchlings of day-21 [duck] or day-17 [quail] live embryos, \% day-14 survivors of normal batchlings, and hatching and day 14 post-hatching body weights). Key definitions were: (1) abnormal eggs were those of reduced or increased size or atypical coloration; (2) cracked or broken eggs were deternined to have fractures via candling; (3) defective eggs were those deemed too snall (at least $15 \%$ smaller than normal) to set, soft-shelled, or membranous; (4) infertile eggs were those that lacked embryos after "set" (unfertilized), (5) normal eggs were exclusive of "abnormal, cracked or broken, defective" categokies; (6) pornal hatchlings were those that matured, pipped the shell, and exited the shell by days 24 or 


\begin{tabular}{|c|c|c|c|c|c|}
\hline \multirow{2}{*}{ Species } & \multirow{2}{*}{$\begin{array}{c}\text { Strychnine } \\
\text { Diet }(\mu g / g)\end{array}$} & \multicolumn{4}{|c|}{ Period (days) } \\
\hline & & (19) & & $(140)$ & (21) \\
\hline \multirow{4}{*}{$\begin{array}{l}\text { Mallard } \\
\text { Duck }\end{array}$} & 0 & 0 & $F_{a}$ Di & Exposure & \multirow{4}{*}{ 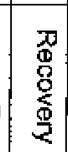 } \\
\hline & 35 & $\frac{\mathrm{c}}{\mathrm{w}}$ & 7-h light & 17-h light & \\
\hline & 70 & 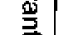 & & Fan Production & \\
\hline & 140 & $\overline{\bar{\phi}}$ & (63) & $(77)$ & \\
\hline
\end{tabular}

\begin{tabular}{|c|c|c|c|c|}
\hline \multirow{2}{*}{ Species } & \multirow{2}{*}{$\begin{array}{l}\text { Strychnine } \\
\text { Diet }(\mu g / g)\end{array}$} & \multicolumn{3}{|c|}{ Peniod (days) } \\
\hline & & (32) & & $(149)$ \\
\hline \multirow{4}{*}{$\begin{array}{l}\text { Northern } \\
\text { Bobwhite } \\
\text { Quail }\end{array}$} & 0 & $\rho$ & \multicolumn{2}{|c|}{$\bar{F}_{o}$ Diet Exposure } \\
\hline & 300 & 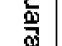 & 7-h light & 17-h light \\
\hline & 600 & $\stackrel{3}{3}$ & & Egg Production \\
\hline & 1200 & $\overrightarrow{\overline{1}}$ & (63) & (86) \\
\hline
\end{tabular}

Fig. 1. Design schematics for the mallard duck and northem bobwhite quail studies

25 of incubation for quail and days 27 or 28 of incubation for ducks (i.e., pipped but not liberated is important here because this measurement shows how long the embryo survived prior to death). Additionally, hatchling body weights were taken at the time of hatching and at day 14.

Following a 19-day quarantine, the 16 pairs of ducks received 140 days of exposure to the respective diets, followed by a 21 -day recovery period, during which the control diet was fed to 12 pairs of randomly selected ducks from each of the four diet groups (only 11 pairs of ducks and a lone male comprised the mean $33.2 \mu g / g$ group). The remaining pairs were euthanized prior to the start of the recovery period (in these studies, euthanasia was by cervical dislocation). The quail study involved a 32-day quarantine period followed by 154 days of exposure of the $F_{v}$ quail to the respective diets, without a recovery period.

$F_{0}$ generation ducks were weighed at the start of the study and at the end of weeks $2,4,6,20$ (start of the recovery period), and 23 (end of the study). Quail were weighed at the start of the sndy and after weeks $2,4,6$, 8,10 , and 22. In both studies, gravimetric estimates (corrected for spillage) of daily diet consumption (g) were made for each pair of $F_{0}$ generation birds. Spillage was measured at the time of replenishment.

During the strychnine-diet periods, both $\mathrm{F}_{0}$ generation ducks and quail were checked daily for toxic signs (e.g., apnea, asthenia, ataxia).

Light schedules were changed to induce egg production. With the exception that the ducks received standard fluorescent light exposure for 7 h daily during week 1 , Design $50^{\text {Tag }}$ Daylite Spectrom fuorescent tubes (Osram Sylvania, Versailles, KY) were used to simulate natural sunlight in each study. A 7 -h on/17-h off light schedule was maintained for each species daring the first 8 weeks; at the beginning of week 9 , this light schedule was reversed. Switching from the 7 -h to the 17-h "on" light period occurred on day 57 for the $F_{0}$ generation ducks, with a subsequent 106-day egg-production period. The first duck egg hatched 90 days after the adult ducks were first exposed to diets. Day 57 of the strychnine-diet period for quail marked the start of the $17-\mathrm{h}$ "on" light schedule; the fitst quail egg hatched 115 days after the adult quail were first exposed to diets.

Eggs were collected and counted during multiple 7-day collection periods. Egg production was based on the number of eggs laid per week per hen. All normal and abnomal eggs (i.e, unless too small to "set") were placed in an egg-storage room $\left(17-20^{\circ} \mathrm{C} ; \mathrm{RH} 73 \%\right)$; eggs were turned once daily during this period. Eggs were "batch" incubated on a weekly basis using five incubators (Jamesway Incubator-Hatcher, Model 252B, Ft. Atkinson, WI) having a mean wet- and dry-bulb temperature from 30.7 to 32.4 and 37.6 to $37.7^{\circ} \mathrm{C}$, respectively, with a mean $\mathrm{RH}$ from 60 to $69 \%$. Throughout incubation, the eggs were turned automatically every $2 \mathrm{~h}$ and candled on days 14 and 21 (mallards) or days 10 and 17 (quail) to ascertain fertility/embryo survival, On day 23 (mallards) or day 21 (quail), eggs were placed in hatching trays; and on day 27 or 28 (ducks) or day 24 or 25 (quail), the hatched ducklings and chicks were removed from the respective incubator as they hatched (i.e, all unhatched eggs were not removed from the incubator until day 28 [ducks] or day 25 [quail], respectively).

The ducklings and chicks were isolated according to $\mathrm{F}_{0}$ generationdiet groups and pairs; ducklings and chicks were housed in a room separate from the adult ducks/quail. These ducklings/chicks were fed untreated diet and water (ad libitum) for 14 days post-hatching, observed daily for potential signs of teratogenesis, and euthanized upon completion of the 14-day period.

Necropsies were perfomed on all ducks and quail that died during the studies; four pairs of surviving adult ducks and eight pairs of surviving adult quail from each diet group were also euthanized and examined at the end of the strychnine-diet period: four pairs of ducks were necropsied at the end of the recovery penod. Gross pathology examinations focused on the gastrointestional (GI) tract, liver, kidneys. heart, reproductive organs, and spleen; subcutaneous fat and muscle samples were also checked for status and possible deterioration.

\section{Statistical Analyses}

Diverse statistical procedures were used to analyze the data; all statistical tests were based on a significance level of $\alpha \leq 0,05$.

Diet Uniformity: Sampled batches of each test diet ( $\mu \mathrm{g} / \mathrm{g}$ strychnine) were analyzed using separate, one-way analyses of variance (ANOVAs); these involved dual samples having three analytical replicates each (Winer 1971). PROC GLM software was used to assess mean $\mu \mathrm{g} / \mathrm{g}$ differences among batches; the "NOINT" option of SAS compared batch means to the intended (nominal) concentration (SAS institute 1989). Post hoc Duncan multiple range tests were used to further test significant sources of variance (Duncan 1955). ANOVAs were not computed for the control diets (MLODs $<3 \mu g / g$ ).

Clinical Sign, Mortality, Gross Pathology in $F_{0}$ Ducks and Oual and $F$, Ducklings and Chicks: These data were summarized descriptively (e.g., frequencies, anatomical significance, onset times stated in text).

Body Weight and Diet Consumption in $F_{0}$ Ducks and Quail: Separate one-way, independent-groups ANOVAs were computed across diet groups for the body weights (g) of adult male and female ducks at weeks $0,2,4,6,20$, and 23 (Winer 1971); similar ANOVAs were computed for weights of adult male and female quail at weeks $0,2,4,6$, 8,10 , and 22 (Winer 1971). Separate one-way, independent-groups ANOVAs were also computed across diet groups for diet consumption (g) of each pait (pen) of ducks/quail during biweekly periods (weeks 2 , $4,6,8,10$, etc.) (Winer 1971). Significant ANOVA effects were further analyzed using post hoc Dunnett's tests, which compared biweekly means of each diet group to the control-diet group, respectively (see Dunnett 1955; Winer 1971).

Egg Production. Embryos, and Hatchlings of $F_{0}$ Ducks and Quail: The egg production counts for ducks were analyzed separately for the strychnine-diet and recovery periods; egg production of quail involved only a strychnine-diet period. For the ratio (\%) variables, both actual percentage and arcsine transformed measurements (Winer 1971) were first analyzed using Leqene's test ( $\alpha \geq 0.01$ ) for determinations of homogeneity or heterogeneity of variances (Levene 1960). If equality 
of variances occurted, separate one-way, independent-groups ANOVAs and Dunnett's tests comparing each respective group to the control were computed among diet categories for the respective variable (Winer 1971; Dunnett 1955); if inequality of variances occurred, separate nonparametric Wilcoxin ranks sums tests were used for those respective variables (Hollander and Wolfe 1973). The use of untransformed ratio variables was given priority. Micrometer measurements of eggshell thickness were made in triplicate on each sampled shell; these were averaged for data analysis. Accidentally cracked or broken eggs (technician miscues, not those cracked by fow in cages) that occurted during a collection interval were saved and used for thickness determinations only if these occurred on days designated for eggshell thickness measurements; otherwise, randomly selected eggs were used for eggshell thickness deteminations.

$F_{1}$ Generation Ducklings and Chicks: These vatiables were analyzed analogous to those of the $F_{0}$ generation ducks and quail.

\section{Results}

\section{Mallard Duck Study}

Dief Uniformity: Mean ( $(\mathrm{SD}$ ) strychnine concentrations for samples of the 35,70 , and $140 \mu \mathrm{g} / \mathrm{g}$ tominal diets were 33.2 $( \pm 2.7), 68.9( \pm 1.8)$, and $140.9( \pm 5.1) \mu g / g$ strychnine, respectively (Figure $2 \mathrm{a}$ ). Only 1 of 20 (5\%) analyzed batches (weeks) of test diets exceeded the arbitrary $\pm 15 \%$ of nominal criterion, with 14 of $20(70 \%)$ batches yielding mean concentrations within $\pm 5.0 \%$ of the intended concentrations.

ANOVAs for respective diets showed that significant batch differences occurred for the mean $33.2 \mu \mathrm{g} / \mathrm{g}$ diet $(\mathrm{F}=3.46$, $\mathrm{df}=7 / 8, \mathrm{p}<0.0516)$, but no significant batch effects were noted for the mean 68.9 ( $F=0.45$, df $=5 / 6, \mathrm{p}<0.7987)$ and $140.9 \mu g / g$ samples ( $\mathrm{F}=1.90$, df $=5 / 6, \mathrm{p}<0.2290$ ). Regarding the $33.2 \mu \mathrm{g} / \mathrm{g}$ batches, post hoc Duncan multiple range tests revealed that the batch $17(37.3 \mu \mathrm{g} / \mathrm{g})$ mean was higher and the batch 9 mean $(29.3 \mu \mathrm{g} / \mathrm{g})$ was lower, than other batch means. Analyses for batch 9 of the $35 \mu \mathrm{g} / \mathrm{g}$ diet yielded $29.3 \mu \mathrm{g} / \mathrm{g}$ strychnine, but analyses of the weeks 8 and 10 samples showed this deviation from nominal was anomalous.

Clinical Sign, Mortality, and Gross Pathology in $F_{0}$ Ducks: Clinical signs of toxicosis were noted for $1(9)$ and $6(49$ and 20) $F_{0}$ generation ducks in the 68.9 and $140.9 \mu \mathrm{g} / \mathrm{g}$ diet groups, respectively. Signs occurred between weeks 6 and 16 of the study only; these included loss of righting reflex, legs stretched behind the body, tremors, spasms, and wing-beat convulsions.

Only 1 of the $32 \mathrm{~F}_{0}$ generation ducks ( $3.1 \%$ ) died during the study (week 7), and this was a hen fed the mean $33.2 \mu \mathrm{g} / \mathrm{g}$ strychnine diet. Postmortem necropsy revealed a red, gel-like substance at the base of the heart and intestines that was slightly gaseous.

Otherwise, few gross pathologies were evident in duck carcasses examined either post-strychnine diet or postrecovery periods (i.e., $1 \delta$ fed the $33.2 \mu \mathrm{g} / \mathrm{g}$ diet displayed small testes, 19 fed the $68.9 \mu \mathrm{g} / \mathrm{g}$ diet had a pale liver, and $1 \delta$ fed the $140.9 \mu \mathrm{g} / \mathrm{g}$ diet showed enlarged intestinal vessels). None of these effects were believed attributable to strychnine.
Body Weight and Diet Consumption in $F_{0}$ Ducks: Female ducks fed the $140.9 \mu \mathrm{g} / \mathrm{g}$ strychnine diet had gained $99.9 \mathrm{~g}$ less body weight than control females at week $20(p<0.05)$, a mean difference that was alleviated during the recovery period (Figure 3). This was the only significant body weight effect observed for the $F_{0}$ generation ducks.

No statistically significant differences in diet consumption were noted for the adult ducks; subchronic ingestion of strychnine alkaloid at these dosages had no adverse effects on diet consumption in $\mathrm{F}_{0}$ generation mallards.

Egg Production, Embryos, and Hatchlings of $F_{0}$ Ducks: Egg production, embryos, and hatchlings data for $F_{0}$ ducks are summarized in Tables 1 and 2 . Hens in each of the strychninediet groups began egg production between weeks 8 and 10 of the study. During both the strychnine-diet and recovery periods, mean eggs laid and mean normal eggs laid per hen in the 140.9 $\mu \mathrm{g} / \mathrm{g}$ group were significantly reduced relative to hens in the control group ( $\mathrm{p} \leq 0.05$ ), an effect that was not reversed during the recovery period. Mean ( $\pm S D$ ) eggs laid by hens in the control, 33.3, 68.9, and $140.9 \mu \mathrm{g} / \mathrm{g}$ diet groups during the strychnine-diet and recovery periods were $45( \pm 21), 49( \pm 13)$, $42( \pm 14)$, and $27( \pm 15)$ versus $8( \pm 7), 12( \pm 10), 4( \pm 7)$, and 1 $( \pm 2)$, respectively.

No other statistically significant adverse effects on reproduction were noted in the adult mallards. Egg fertility (\% viable embryos or eggs set) and live 21-day embryos exceeded $84 \%$ and $90 \%$ across groups, respectively; these data did not differ from those of hens fed control diet. Minimum-maximum batch values $(\%)$ during the strychnine-diet period (based on live 21-day embryos) were $71 \%$ and $83 \%$ for test groups; these compared to $87 \%$ of the eggs hatched from ducks fed control diet. Mean ( \pm SD) eggshell thickness for eggs of hens in the control, $33.2,68.9$, and $140.9 \mu \mathrm{g} / \mathrm{g}$ strychnine diet groups were $0.383( \pm 0.028), 0.387( \pm 0.019), 0.392( \pm 0.019)$, and 0.383 $( \pm 0.025) \mathrm{mm}$ and $0.371( \pm 0.048), 0.356( \pm 0.011), 0.375$ $( \pm 0.016)$, and $0.348( \pm 0.002) \mathrm{mm}$, during the strychnine-diet and recovery periods, respectively.

Effects in $F_{/}$Generation Ducklings: Hatchlings from eggs of mallards fed 68.9 and $140.9 \mu \mathrm{g} / \mathrm{g}$ strychnine diets averaged significantly less body weight $(\mathrm{p} \leq 0.05)$ relative to hatchlings from control-diet-fed mallards; this effect occurted for the offspring in the 13 and 3 hatches comprising the strychnine-diet and recovery periods. Mean ( $\pm S D$ ) hatchling body weights of ducklings fed control, $33.2,68.9$, and $140.9 \mu \mathrm{g} / \mathrm{g}$ strychnine diets were $37.4( \pm 2.5), 36.6( \pm 1.6), 35.4( \pm 2.7)$, and 34.0 $( \pm 2.6) \mathrm{g}$ during the strychnine-diet period and $38.9( \pm 3.0)$, $37.6( \pm 2.1), 34.2( \pm 4.4)$, and $33.4( \pm 4.8) \mathrm{g}$ during the recovery period, respectively. This body weight effect was alleviated rapidly, as it was obscured by duckling weight gains within 14 days after hatching.

Few ducklings displayed clinical signs during the 14-day post-hatch observations. Specifically, two ducklings from mallards fed $68.9 \mu \mathrm{g} / \mathrm{g}$ strychnine diets showed signs; one was lethargic on the first day after hatching in the sixth hatch, and one was euthanized on the first day after hatching in the 12 th hatch (weak, unabie to ambulate well, and a partially closed 

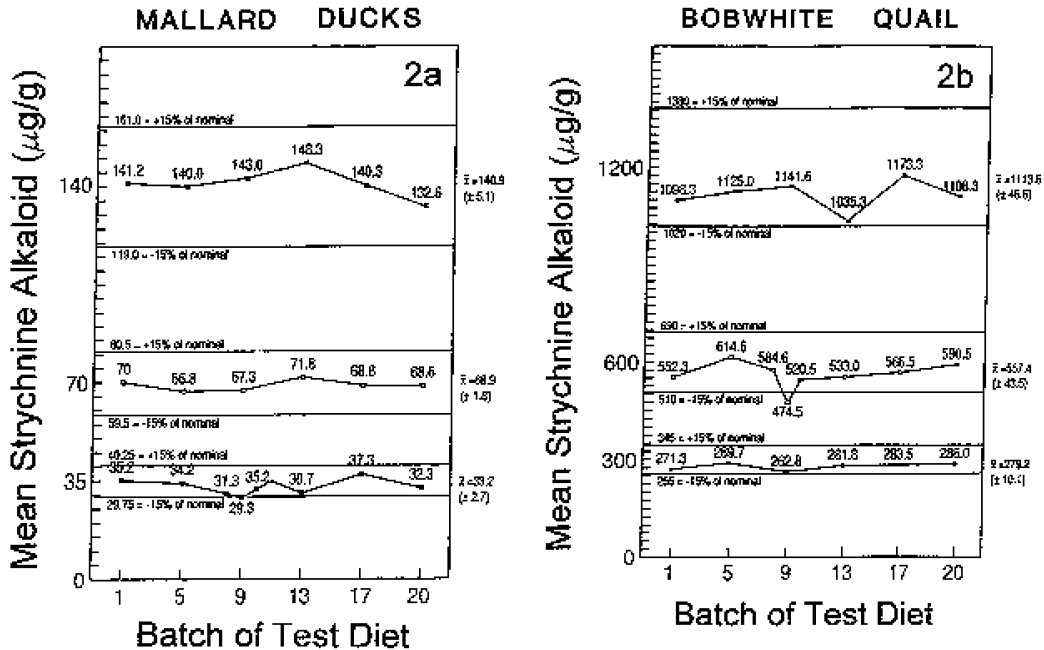

Fig. 2. Mean strychnine determinations ( $\mu g / g)$ for batch (week) $1,5,9,13,17$, and 20 Punina ${ }^{\text {(i) Game }}$ Bird Layena diet samples prepared for mallard ducks (a) and bobwhite quail (b); solid lines bracketing dietary values are $\pm 15 \%$ of nominal (note-Analytical determinations for batches 8 and 10 of the $35 \mathrm{~kg} / \mathrm{g}$ and $600 \mu \mathrm{g} / \mathrm{g}$ diets were performed because the batch 9 samples exceeded $\pm 15 \%$ of the intended mix)

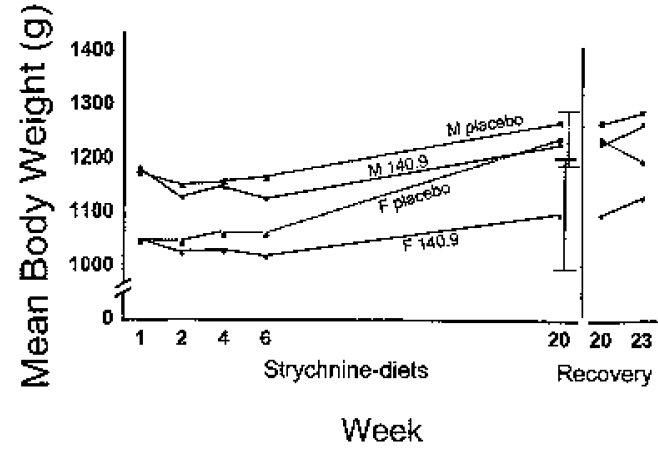

Fig. 3. Mean body weights of $F_{0}$ generation male and femate mallard ducks fed $140.9 \mu \mathrm{g} / \mathrm{g}$ strychnine diets relative to the control diet-fed ducks; this is the only significant body weight effect for the aduit ducks

eye). Additionally, two ducklings from control-diet docks and one from $33.2 \mu \mathrm{g} / \mathrm{g}$-fed ducks had cage-related injuries during the study.

Minimum-maximum 14-day survival rates of ducklings were $96 \%$ and $99 \%$ during the strychnine-diet period. Egg production was decreased in the $140.9 \mu \mathrm{g} / \mathrm{g}$ group. Mean ( \pm SD) surviving ducklings per hen from those fed control $(0.0), 33.2$, 68.9 , and $140.9 \mu \mathrm{g} / \mathrm{g}$ strychnine diets were 30 ( \pm 16 ), $30( \pm 9$ ), $24( \pm 13)$, and $14( \pm 11)$; however, because of the high within-group variance, these differences were not statistically significant.

For the recovery period, mean numbers of surviving duck lings per hen on day 14 were significantly reduced for adult ducks formerly fed $140.9 \mu \mathrm{g} / \mathrm{g}(\mathrm{p} \leq 0.05$ ). Mean ( $\pm \mathrm{SD}$ ) numbers of survivors per hen for control, 33.2, 68.9, and 140.9 $\mu \mathrm{g} / \mathrm{g}$ strychnine diet groups in recovery were $5( \pm 5), 9( \pm 7), 3$ $( \pm 5)$, and $0.17( \pm 1)$ ducklings, respectively.

Ten ducklings out of 33 that were found dead during the 14-day post-hatch observations displayed abnormal pathological findings. That is, abnormal signs were noted in one, five, and four ducklings that had hatched from eggs of hens fed control, 33.2 , and $68.9 \mu \mathrm{g} / \mathrm{g}$ strychnine diets, respectively. Necropsies of these ducklings tevealed: control-pale liver for the hatch 9 duckling; $33.2 \mu \mathrm{g} / \mathrm{g}$ offspring--pale, yellow livers for the five hatch 10 ducklings; $68.9 \mu g / g$ offspring-red, gel-like substance circumscribing a pale liver for one hatch 9 duckling, plus pale, yellow livers for two hatch 10 ducklings, and a friable liver for one hatch 12 duckling. No gross pathology was found for the ducklings from respective diet groups that were euthanized for experimental purposes on day 14 of respective hatches.

\section{Bobwhite Quatl Study}

Diet Uniformity: These diets contained means ( \pm SD) of 279.2 $( \pm 10.1), 557.4( \pm 43.5)$, and $1,113.6( \pm 46.6) \mu \mathrm{g} / \mathrm{g}$ strychnine, respectively (Figure 2b). Mean strychnine concentrations for 1 of $20(5.0 \%)$ batches fed to the quail exceeded an arbitrary $\pm 15 \%$ of nominal criterion (batch $9: 600 \mu \mathrm{g} / \mathrm{g}$ nominal); 16 of $20(80 \%)$ batches yielded mean $\mu \mathrm{g} / \mathrm{g}$ strychnine within $\pm 10.0 \%$ of the intended concentrations. The batch $9 \mathrm{mix}$ for the $600 \mathrm{\mu g} / \mathrm{g}$ strychnine diet led to additional chemical analyses of batches 8 and 10 samples; these were within $15 \%$ of the intended concentra tion and the mixing departure was considered anomalous.

ANOVAs of the quail diets yielded no significant differences among batches for the mean $279.2(F=1.38, \mathrm{df}=5 / 6$, $\mathrm{p}<0.3492), 557.4(\mathrm{~F}=2.32, \mathrm{df}=7 / 8, \mathrm{p}<0.1308)$, or $1,113.6$ $(\mathrm{F}=0.56, \mathrm{df}=5 / 6, \mathrm{p}<0.7322) \mu \mathrm{g} / \mathrm{g}$ strychnine diets. Nevertheless, the series of single degree of freedom tests (NONT option) used to compare each mean against the nominal concentration showed that batches 1 and 9 of the $300 \mathrm{fg} / \mathrm{g}$, batches 8 and 20 of the $600 \mu \mathrm{g} / \mathrm{g}$, and batch 13 of the $1,200 \mu \mathrm{g} / \mathrm{g}$ diets differed from the intended concentrations.

Clinical Sign, Mortality and Gross Pathology in $F_{0}$ Quail: Early in the study, excoriation (i.e., a linear break in the skin surface, usually covered with blood or serous crusts) developed in either the tarsal/metatarsal areas, legs, or anterior portion of the head in a number of quail. This was considered a stressinduced effect of increased activity with initiation of the $17-\mathrm{h}$ light schedule (i.e., to promote egg production). Altogether, 40 of the quail eventually displayed excoriation-12 in the control, 11 in the $300 \mu \mathrm{g} / \mathrm{g}, 9$ in the $600 \mu \mathrm{g} / \mathrm{g}$, and 8 in the $1,200 \mu \mathrm{g} / \mathrm{g}$ diet 
Table 1. Composite egg production/embryo/hatchling data for mallard ducks and bobwhite quail

\begin{tabular}{|c|c|c|c|c|}
\hline & \multicolumn{4}{|c|}{ Strychnine Diet Concentration $(\bar{x} \mu g / g)$} \\
\hline & Control & 33.2 & 689 & 140.9 \\
\hline \multicolumn{5}{|l|}{ Ducks } \\
\hline \multicolumn{5}{|l|}{$\begin{array}{c}\text { Strychnine-diet period } \\
\text { (20 weeks) }\end{array}$} \\
\hline Eggs laid & 714 & 728 & 672 & 435 \\
\hline \multicolumn{5}{|l|}{ Eggs cracked or } \\
\hline broken & 10 & 6 & 11 & 8 \\
\hline Eggs set ${ }^{b}$ & 653 & 662 & 605 & 394 \\
\hline Viable embryos & 601 & 603 & 526 & 323 \\
\hline Live 21-day embryos & 574 & 554 & 488 & 292 \\
\hline Normal hatchlings & 493 & 457 & 385 & 224 \\
\hline 14-day-old survivors & 482 & 446 & 379 & 222 \\
\hline \multicolumn{5}{|l|}{$\begin{array}{l}\text { Recovery period' ( } 3 \\
\text { weeks; adults fed } \\
\text { control diet) }\end{array}$} \\
\hline Eggs laid & 92 & 129 & 48 & 15 \\
\hline \multicolumn{5}{|l|}{ Eggs cracked or } \\
\hline broken & 1 & 2 & 0 & 1 \\
\hline Eggs set ${ }^{\mathrm{b}}$ & 83 & 119 & 45 & 11 \\
\hline viable embryos & 71 & 118 & 43 & 7 \\
\hline Live 21-day embryos & 66 & 110 & 40 & 6 \\
\hline Nomal hatchlings & 60 & 95 & 34 & 5 \\
\hline \multirow[t]{3}{*}{ 14-day-old survivors } & 60 & 95 & 34 & 2 \\
\hline & \multicolumn{4}{|c|}{ Strychnine Diet Concentration $(\bar{x} \mu g / g)$} \\
\hline & Control & 279.2 & 557.4 & 1113.6 \\
\hline \multicolumn{5}{|l|}{ Quail (22 weeks) } \\
\hline \multicolumn{5}{|l|}{$\begin{array}{l}\text { Strychnine-diet period } \\
\text { (22 weeks) }\end{array}$} \\
\hline Eggs laid & 668 & 590 & 627 & 639 \\
\hline \multicolumn{5}{|l|}{ Eggs cracked or } \\
\hline broken & 28 & 15 & 14 & 21 \\
\hline Eggs set & 570 & 519 & 555 & 554 \\
\hline Viable embryos & 535 & 480 & 537 & 519 \\
\hline Live 17-day embryos & 521 & 475 & 530 & 513 \\
\hline Normal hatchlings & 460 & 428 & 485 & 481 \\
\hline 14-day-old survivors & 402 & 379 & 418 & 421 \\
\hline
\end{tabular}

${ }^{a}$ One female duck fed $33.2 \mu g / g$ strychnine diet died (week 7 )

${ }^{b}$ Eggs set were those that were neither cracked nor broken, nor too small to set, nor soft-shelled, nor membranous, nor used for eggshell thickness determinations

c Four female ducks were euthanized at the end of the strychnine-diet period for gross pathology examinations

groups. These quail were treated daily with antibiotic ointment (Bacitracin-Neomycin-Polymyxin B); aIso, to stop pecking by mates, nasal rings were inserted in some male beaks. Occasional fighting (typical behavior for breeding bobwhite quail) was also observed in some adult quail during the study; this declined near the end of egg production.

Two adult quail ( $q$ ) died and one ( $q$ ) was enthanized during the study. One hen in the $1,113.6 \mu \mathrm{g} / \mathrm{g}$ strychnine group appeared to have gotten its head caught in the cage and was found dead. Additionally, one hen fed $557.4 \mu \mathrm{g} / \mathrm{g}$ strychnine was found dead with severe excoriation, and another hen fed 1,113.6 $\mu \mathrm{g} / \mathrm{g}$ strychnine was euthanized due to severe excoriation.

Gross pathology yielded inconsistent and few if any strych- nine-related effects. Of 16 examinations performed on quail fed the control diet, five (one $\delta$, four $q$ ) showed mild excoriation of the legs or feet, and two ( 9 ) showed pale livers. Of 16 quail examined from the $279.2 \mu \mathrm{g} / \mathrm{g}$ group, one ( $\sigma^{*}$ ) showed mild excoriation and one ( 9 ) showed a mottled liver. of 17 quail fed $557.4 \mu \mathrm{g} / \mathrm{g}$ strychnine, two (O) were necropsied during the study - one was found dead and one was euthanized; additionally, 15 quail were examined at the end of the study. The quail with severe excoriation of the feet and right knee also had impacted intestines, white excreta around the vent, an enlarged friable liver, and a crop void of diet. The euthanized hen showed severe excoriation to the legs, wings, and vent areas, plus impacted lower intestines, black-colored upper intestines, and a crop void of diet. Of the remaining quail, two ( $\hat{\sigma}$ ) showed pale or friable livers, two ( $\delta$ ) showed mild excoriation, and one ( $q$ ) showed a mottled liver. of 17 quail examined in the 1,113.6 $\mu g / g$ group, two (ठ) showed excoriation, one (ठ) showed a pale liver, one ( $P$ ) showed gaseous lower intestines plus enlarged upper intestines, and one ( $q$ ) showed gaseous lower intestines.

Body Weight and Diet Consumption in $F_{0}$ Quail: Despite monotonic increased mean body weights for male and female quail in each diet group during the 22 weeks of the study, no statistically significant shifts in body weight due to strychnine diets occurred. Lightest and heaviest mean weights of quail in diet groups invariably occurred for the initial and final weighing - a growth effect. Female quail invariably gained more weight than their mates, but variances across strychnine-diet groups obscured any gender and group differences. Mean initial to final weight changes $(\mathrm{g})$ for males in the control, 279.2 , 557.4 , and $1,113.6 \mu \mathrm{g} / \mathrm{g}$ strychnine groups were $15.8,12.7$, 14.5 , and $14.7 \mathrm{~g}$, respectively, whereas mean weight shifts for females in these groups were $43.5,38.8,44.7$, and $41.4 \mathrm{~g}$, respectively.

No statistically significant effects on diet consumption due to strychnine diets occurred for adult quail. Minimum-maximum mean ( \pm SD) diet consumption estimates (g/quail/day) for quail in the control, 279.2, 557.4, and 1,113.6 $\mu \mathrm{g} / \mathrm{g}$ strychnine groups were $15.8( \pm 1.9)-21.7( \pm 3.3), 16.3( \pm 2.8)-21.3( \pm 2.9), 17.0$ $( \pm 3.1)-22.8( \pm 3.2)$, and $16.9( \pm 3.1)-21.7( \pm 2.3)$, respectively.

Egg Production, Embryos, and Hatchlings of $F_{0}$ Quail: Egg production was monitored the same as was described for ducks (Tables 1 and 3). With the exception of one hen in the 1,113.6 $\mu \mathrm{g} / \mathrm{g}$ strychnine group that laid nine eggs during weeks $1-3$ and then stopped laying until week 15, quail came into egg production during weeks 12 and 13 of the study. Mean ( \pm SD) eggs laid by hens in the control, $279.2,557.4$, and $1,113.6 \mu \mathrm{g} / \mathrm{g}$ strychnine groups were $42( \pm 16), 37( \pm 21), 39( \pm 19)$, and 40 $( \pm 14)$, respectively.

No statistically significant differences in eggshell thickness were noted. Mean $( \pm S D$ ) shell thickness of eggs produced by hens fed control, $279.2,557.4$, and $1,113.6 \mu \mathrm{g} / \mathrm{g}$ strychnine diets were $0.205( \pm 0.022), 0.217( \pm 0.014), 0.210( \pm 0.018)$, and $0.210( \pm 0.017) \mathrm{mm}$, respectively.

No effects on egg quality, stage of embryonic development, or hatchability of quail eggs were found at the current dietary 
Table 2. Mean (SD and $n$ ) of duck reproductive variables for 13 and 3 hatches of the strychnine-diet and recovery periods, respectively

\begin{tabular}{|c|c|c|c|c|c|c|c|c|}
\hline \multirow[b]{2}{*}{ Variable } & \multicolumn{4}{|c|}{ Strychnine Diet $(\mu \mathrm{g} / \mathrm{g})$} & \multicolumn{4}{|c|}{ Recovery (Adults Fed Control Diet) } \\
\hline & Control & 33.2 & 68.9 & 140.9 & Control & {$[33.2]$} & {$[68.9]$} & {$[140.9]$} \\
\hline Eggs laid per hen & $\begin{array}{l}45 \\
(21) \\
(n=16)\end{array}$ & $\begin{array}{l}49 \\
(13) \\
(\mathrm{n}=15)\end{array}$ & $\begin{array}{l}42 \\
(14) \\
(n=16)\end{array}$ & $\begin{array}{l}27 \\
(15) \\
(n=16)\end{array}$ & $\begin{array}{c}8 \\
(7) \\
(0=12)\end{array}$ & $\begin{array}{l}12 \\
(10) \\
(\mathrm{n}=11)\end{array}$ & $\begin{array}{c}4 \\
(7) \\
(n=12)\end{array}$ & $\begin{array}{c}\mathbf{l}^{\mathrm{b}} \\
(2) \\
(\mathrm{n}=12\end{array}$ \\
\hline Nomal eggs per hen & $\begin{array}{l}43 \\
(21) \\
(n=16)\end{array}$ & $\begin{array}{l}48 \\
(13) \\
(n=15)\end{array}$ & $\begin{array}{l}40 \\
(15) \\
(n=16)\end{array}$ & $\begin{array}{l}26^{a} \\
(15) \\
(n=16)\end{array}$ & $\begin{array}{c}8 \\
(7) \\
(n=12)\end{array}$ & $\begin{array}{c}11 \\
(10) \\
(\mathrm{n}=11)\end{array}$ & $\begin{array}{c}4 \\
(7) \\
(n=12)\end{array}$ & $\begin{array}{c}\mathbf{l}^{\mathrm{b}} \\
(\mathrm{n}=12\end{array}$ \\
\hline $\begin{array}{l}\text { Normal eggs of eggs laid } \\
(\%)\end{array}$ & $\begin{array}{l}95 \\
(7) \\
(n=15)\end{array}$ & $\begin{array}{l}98 \\
(2) \\
(n=15)\end{array}$ & $\begin{array}{l}94 \\
(7) \\
(n=16)\end{array}$ & $\begin{array}{l}95 \\
(6) \\
(n=15)\end{array}$ & $\begin{array}{c}98 \\
(5) \\
(n=10)\end{array}$ & $\begin{array}{c}97 \\
(5) \\
(n=8)\end{array}$ & $\begin{array}{c}92 \\
(12) \\
(n=4)\end{array}$ & $\begin{array}{c}96 \\
(7) \\
(n=4)\end{array}$ \\
\hline $\begin{array}{l}\text { Abnormal eggs of eggs } \\
\text { laid (\%) }\end{array}$ & $\begin{array}{l}3 \\
(7) \\
(n=15)\end{array}$ & $\begin{array}{c}1 \\
(2) \\
(n=15)\end{array}$ & $\begin{array}{l}3 \\
(5) \\
(n=16)\end{array}$ & $\begin{array}{l}3 \\
(4) \\
(n=15)\end{array}$ & $\begin{array}{c}0 \\
(0) \\
(n=10)\end{array}$ & $\begin{array}{c}2 \\
(5) \\
(n=8)\end{array}$ & $\begin{array}{c}8 \\
(12) \\
(n=4)\end{array}$ & $\begin{array}{c}0 \\
(0) \\
(n=4)\end{array}$ \\
\hline $\begin{array}{l}\text { Cracked/broken eggs of } \\
\text { eggs laid (\%) }\end{array}$ & $\begin{array}{l}1 \\
(2) \\
(n=15)\end{array}$ & $\begin{array}{c}1 \\
(1) \\
(n=15)\end{array}$ & $\begin{array}{l}2 \\
(3) \\
(n=16)\end{array}$ & $\begin{array}{l}2 \\
(3) \\
(\mathbf{n}=15)\end{array}$ & $\begin{array}{c}2 \\
(5) \\
(n=10)\end{array}$ & $\begin{array}{c}1 \\
(2) \\
(n=8)\end{array}$ & $\begin{array}{c}0 \\
(0) \\
(n=4)\end{array}$ & $\begin{array}{c}4 \\
(7) \\
(\pi=4)\end{array}$ \\
\hline $\begin{array}{l}\text { Defective eggs of eggs } \\
\text { laid }(\%)\end{array}$ & $\begin{array}{l}0 \\
(1) \\
(n=15)\end{array}$ & $\begin{array}{c}0 \\
(0) \\
(n=15)\end{array}$ & $\begin{array}{c}0 \\
(1) \\
(n=16)\end{array}$ & $\begin{array}{c}1 \\
(2) \\
(n=15)\end{array}$ & $\begin{array}{c}0 \\
(0) \\
(n=10)=10)\end{array}$ & $\begin{array}{c}0 \\
(0) \\
(0=8)\end{array}$ & $\begin{array}{c}0 \\
(0) \\
(n=4)\end{array}$ & $\begin{array}{c}0 \\
(0) \\
(n=4)\end{array}$ \\
\hline $\begin{array}{l}\text { Infertile eggs of eggs set } \\
(\%)\end{array}$ & $\begin{array}{l}12 \\
(25) \\
(n=15)\end{array}$ & $\begin{array}{c}9 \\
(11) \\
(n=15)\end{array}$ & $\begin{array}{l}16 \\
(25) \\
(n=16)\end{array}$ & $\begin{array}{l}15 \\
(28) \\
(n=15)\end{array}$ & $\begin{array}{l}19 \\
(33) \\
(n=10)\end{array}$ & $\begin{array}{c}1 \\
(2) \\
(n=8)\end{array}$ & $\begin{array}{c}6 \\
(8) \\
(n=4)\end{array}$ & $\begin{array}{l}25 \\
(50) \\
(n=4)\end{array}$ \\
\hline Viable embryos of set (\%) & $\begin{array}{l}88 \\
(25) \\
(n=15)\end{array}$ & $\begin{array}{l}91 \\
(11) \\
(n=15)\end{array}$ & $\begin{array}{l}84 \\
(25) \\
(n=16)\end{array}$ & $\begin{array}{l}85 \\
(28) \\
(n=15)\end{array}$ & $\begin{array}{c}81 \\
(33) \\
(n=10)\end{array}$ & $\begin{array}{c}99 \\
(2) \\
(0=8)\end{array}$ & $\begin{array}{c}94 \\
(8) \\
(n=4)\end{array}$ & $\begin{array}{l}75 \\
(50) \\
(0=4)\end{array}$ \\
\hline $\begin{array}{l}\text { Embryo mortalities at one } \\
\text { week of set (\%) }\end{array}$ & $\begin{array}{c}1 \\
(2) \\
(n=15)\end{array}$ & $\begin{array}{l}3 \\
(6) \\
(\mathrm{n}=15)\end{array}$ & $\begin{array}{c}3 \\
(6) \\
(n=16)\end{array}$ & $\begin{array}{l}2 \\
(4) \\
(n=15)\end{array}$ & $\begin{array}{c}1 \\
(2) \\
(n=10)\end{array}$ & $\begin{array}{c}1 \\
(3) \\
(n=8)\end{array}$ & $\begin{array}{c}5 \\
(6) \\
(n=4)\end{array}$ & $\begin{array}{l}0 \\
(0) \\
(n=4)\end{array}$ \\
\hline $\begin{array}{l}\text { Embryo mortalities at } \\
\text { midterm of set }(\%)\end{array}$ & $\begin{array}{l}3 \\
(3) \\
(n=15)\end{array}$ & $\begin{array}{l}4 \\
(5) \\
(n=15)\end{array}$ & $\begin{array}{c}3 \\
(4) \\
(n=16)\end{array}$ & $\begin{array}{c}5 \\
(6) \\
(n=15)\end{array}$ & $\begin{array}{c}4 \\
(8) \\
(n=10)\end{array}$ & $\begin{array}{c}5 \\
(5) \\
(n=8)\end{array}$ & $\begin{array}{c}0 \\
(0) \\
(n=4)\end{array}$ & $\begin{array}{l}25 \\
(50) \\
(n=4)\end{array}$ \\
\hline $\begin{array}{l}\text { Day-21 live embryos of } \\
\text { set }(\%)\end{array}$ & $\begin{array}{l}84 \\
(24) \\
(n=15)\end{array}$ & $\begin{array}{l}85 \\
(12) \\
(n=15)\end{array}$ & $\begin{array}{l}79 \\
(25) \\
(n=16)\end{array}$ & $\begin{array}{l}78 \\
(28) \\
(\mathbf{n}=15)\end{array}$ & $\begin{array}{l}76 \\
(31) \\
(n=10)\end{array}$ & $\begin{array}{c}93 \\
(6) \\
(n=8)\end{array}$ & $\begin{array}{c}90 \\
(9) \\
(n=4)\end{array}$ & $\begin{array}{l}50 \\
(58) \\
(n=4)\end{array}$ \\
\hline $\begin{array}{l}\text { Embryo mortalities at } \\
\text { full-tem of set }(\%)\end{array}$ & $\begin{array}{l}6 \\
(6) \\
(n=15)\end{array}$ & $\begin{array}{l}11 \\
(14) \\
(n=15)\end{array}$ & $\begin{array}{l}10 \\
(9) \\
(n=16)\end{array}$ & $\begin{array}{l}18 \\
(27) \\
(1=15)\end{array}$ & $\begin{array}{c}4 \\
(7) \\
(n=10)\end{array}$ & $\begin{array}{c}6 \\
(9) \\
(n=8)\end{array}$ & $\begin{array}{c}5 \\
(10) \\
(n=4)\end{array}$ & $\begin{array}{c}0 \\
(0) \\
(n=4)\end{array}$ \\
\hline $\begin{array}{l}\text { Pipped not liberated } \\
\text { of set }(\%)\end{array}$ & $\begin{array}{l}5 \\
(4) \\
(n=15)\end{array}$ & $\begin{array}{l}3 \\
(4) \\
(n=15)\end{array}$ & $\begin{array}{c}7 \\
(7) \\
(\mathrm{n}=16)\end{array}$ & $\begin{array}{l}4 \\
(5) \\
(n=15)\end{array}$ & $\begin{array}{c}3 \\
(7) \\
(n=10)\end{array}$ & $\begin{array}{c}5 \\
(4) \\
(n=8)\end{array}$ & $\begin{array}{c}3 \\
(7) \\
(n=4)\end{array}$ & $\begin{array}{l}5 \\
(10) \\
(n=4)\end{array}$ \\
\hline $\begin{array}{l}\text { Day-14 survivors of set } \\
(\%)\end{array}$ & $\begin{array}{l}70 \\
(23) \\
(n=15)\end{array}$ & $\begin{array}{l}69 \\
(19) \\
(n=15)\end{array}$ & $\begin{array}{l}61 \\
(26) \\
(n=16)\end{array}$ & $\begin{array}{l}55 \\
(31) \\
(n=15)\end{array}$ & $\begin{array}{c}70 \\
(33) \\
(n=10)\end{array}$ & $\begin{array}{c}82 \\
(10) \\
(n=8)\end{array}$ & $\begin{array}{c}81 \\
(14) \\
(n=4)\end{array}$ & $\begin{array}{l}10^{b} \\
(20) \\
(n=4)\end{array}$ \\
\hline $\begin{array}{l}\text { Normal hatchlings of } \\
\text { day-21 live embryos } \\
\text { (\%) }\end{array}$ & $\begin{array}{l}87 \\
(8) \\
(n=14)\end{array}$ & $\begin{array}{l}83 \\
(17) \\
(n=15)\end{array}$ & $\begin{array}{l}73 \\
(26) \\
(\mathrm{n}=16)\end{array}$ & $\begin{array}{l}71 \\
(27) \\
(n=14)\end{array}$ & $\begin{array}{l}90 \\
(16) \\
(n=9)\end{array}$ & $\begin{array}{l}89 \\
(11) \\
(n=8)\end{array}$ & $\begin{array}{l}91 \\
(11) \\
(n=4)\end{array}$ & $\begin{array}{l}90 \\
(14) \\
(n=2)\end{array}$ \\
\hline $\begin{array}{l}\text { Day-14 survivors of } \\
\text { normal hatchlings }(\%)\end{array}$ & $\begin{array}{l}96 \\
(8) \\
(n=14)\end{array}$ & $\begin{array}{l}97 \\
(4) \\
(0=15)\end{array}$ & $\begin{array}{l}98 \\
(3) \\
(n=15)\end{array}$ & $\begin{array}{l}99 \\
(2) \\
(n=13)\end{array}$ & $\begin{array}{c}100 \\
(0) \\
(n=9)\end{array}$ & $\begin{array}{c}100 \\
(0) \\
(n=8)\end{array}$ & $\begin{array}{c}100 \\
(0) \\
(n=4)\end{array}$ & $\begin{array}{l}25^{\circ} \\
(35) \\
(n=2)\end{array}$ \\
\hline
\end{tabular}

${ }^{4}$ Sums of normal, abnormal, cracked/broken, defective, and infertile eggs do not always total $100 \%$ because of slight rounding enrors, plus certain categories were not mutually exclusive (e.g., abnomal/reduced and cracked/broken)

b Significantly different from the control $(\mathrm{p}<0.05)$, using a Dunnett's one-tailed test

concentrations of strychnine. Minimum-maximum egg fertility in test group eggs varied between $90-97 \%$, compared with $94 \%$ for eggs of control diet-fed adult quail. Live 17-day embryos for eggs of test group quail varied between $98-99 \%$, compared with $96 \%$ for control diet-fed adult quail. Overall hatch success for eggs of adult quail fed test diets varied between $92-94 \%$, compared with $90 \%$ for control diet-fed quail.
Effects in $F_{I}$ Generation Chicks: The ingestion of strychnine diets by adult quail had no significant effects on the body weight or survivability of chicks at hatch or day 14 post-hatch. Chick survival for 14 days post-hatch equaled $87 \%, 89 \%, 80 \%$, and $86 \%$ for offspring of quail fed control, $279.2,557.4$, and $1,113.6$ $\mu \mathrm{g} / \mathrm{g}$ strychnine diets, respectively.

Regarding clinical signs in chicks, most signs were associ- 
Table 3. Mean (SD and $\mathrm{n}$ ) of quail reproductive variables for 11 hatches of the strychnine-diet period

\begin{tabular}{|c|c|c|c|c|}
\hline \multirow[b]{2}{*}{ Variable } & \multicolumn{4}{|c|}{ Strychnine Diet $(\bar{x} \mu g / g)$} \\
\hline & Control & 279.2 & 557.4 & $1,113.6$ \\
\hline $\begin{array}{l}\text { Eggs laid per hen } \\
\text { (\#) }\end{array}$ & $\begin{array}{l}42 \\
(16) \\
(n=16)\end{array}$ & $\begin{array}{l}37 \\
(21) \\
(n=16)\end{array}$ & $\begin{array}{l}39 \\
(19) \\
(n=16)\end{array}$ & $\begin{array}{l}40 \\
(14) \\
(n=16)\end{array}$ \\
\hline $\begin{array}{l}\text { Normal eggs per } \\
\text { hen (\#) }\end{array}$ & $\begin{array}{l}39 \\
(15) \\
(n=16)\end{array}$ & $\begin{array}{l}36 \\
(21) \\
(n=16)\end{array}$ & $\begin{array}{l}38 \\
(19) \\
(n=16)\end{array}$ & $\begin{array}{l}38 \\
(13) \\
(n=16)\end{array}$ \\
\hline $\begin{array}{l}\text { Normal eggs of } \\
\text { eggs laid }(\%)\end{array}$ & $\begin{array}{l}95 \\
(5) \\
(\mathrm{n}=16)\end{array}$ & $\begin{array}{l}90 \\
(25) \\
(n=16)\end{array}$ & $\begin{array}{l}96 \\
(8) \\
(n=15)\end{array}$ & $\begin{array}{l}96 \\
(4) \\
(n=16)\end{array}$ \\
\hline $\begin{array}{l}\text { Abnomal eggs } \\
\text { of eggs laid } \\
(\%)\end{array}$ & $\begin{array}{l}0 \\
(1) \\
(n=16)\end{array}$ & $\begin{array}{l}0 \\
(0) \\
(\mathrm{n}=16)\end{array}$ & $\begin{array}{l}0 \\
(1) \\
(n=15)\end{array}$ & $\begin{array}{c}0 \\
(0) \\
(n=16)\end{array}$ \\
\hline $\begin{array}{l}\text { Cracked/broken } \\
\text { eggs of eggs } \\
\text { laid (\%) }\end{array}$ & $\begin{array}{l}4 \\
(5) \\
(n=16)\end{array}$ & $\begin{array}{l}4 \\
(9) \\
(n=16)\end{array}$ & $\begin{array}{l}3 \\
(8) \\
(n=15)\end{array}$ & $\begin{array}{l}3 \\
(3) \\
(n=16)\end{array}$ \\
\hline $\begin{array}{c}\text { Defective eggs of } \\
\text { eggs laid (\%) }\end{array}$ & $\begin{array}{l}1 \\
(1) \\
(n=16)\end{array}$ & $\begin{array}{l}6 \\
(25) \\
(\pi=16)\end{array}$ & $\begin{array}{l}0 \\
(1) \\
(n=15)\end{array}$ & $\begin{array}{l}1 \\
(1) \\
(n=16)\end{array}$ \\
\hline $\begin{array}{l}\text { Infertile eggs of } \\
\text { eggs set }(\%)\end{array}$ & $\begin{array}{l}6 \\
(9) \\
(0=16)\end{array}$ & $\begin{array}{l}10 \\
(10) \\
(n=15)\end{array}$ & $\begin{array}{l}3 \\
(3) \\
(n=15)\end{array}$ & $\begin{array}{l}8 \\
(11) \\
(n=16)\end{array}$ \\
\hline $\begin{array}{l}\text { Viable embryos } \\
\text { of set }(\%)\end{array}$ & $\begin{array}{l}94 \\
(9) \\
(n=16)\end{array}$ & $\begin{array}{l}90 \\
(10) \\
(n=15)\end{array}$ & $\begin{array}{l}97 \\
(3) \\
(n=15)\end{array}$ & $\begin{array}{l}92 \\
(11) \\
(n=16)\end{array}$ \\
\hline $\begin{array}{l}\text { Embryo mortali- } \\
\text { ties at one } \\
\text { week of set } \\
\text { (\%) }\end{array}$ & $\begin{array}{l}2 \\
(4) \\
(n=16)\end{array}$ & $\begin{array}{l}0 \\
(1) \\
(n=15)\end{array}$ & $\begin{array}{l}2 \\
(5) \\
(n=15)\end{array}$ & $\begin{array}{c}0 \\
(1) \\
(\mathrm{n}=16)\end{array}$ \\
\hline $\begin{array}{l}\text { Embryo mortali- } \\
\text { ties at midterm } \\
\text { of set (\%) }\end{array}$ & $\begin{array}{l}1 \\
(3) \\
(n=16)\end{array}$ & $\begin{array}{c}1 \\
(3) \\
(n=15)\end{array}$ & $\begin{array}{c}1 \\
(2) \\
(n=15)\end{array}$ & $\begin{array}{l}1 \\
(1) \\
(n=16)\end{array}$ \\
\hline $\begin{array}{l}\text { Day- } 17 \text { live } \\
\text { embryos of set } \\
\text { (\%) }\end{array}$ & $\begin{array}{l}91 \\
(16) \\
(\mathrm{H}=16)\end{array}$ & $\begin{array}{l}89 \\
(10) \\
(n=15)\end{array}$ & $\begin{array}{l}95 \\
(6) \\
(n=15)\end{array}$ & $\begin{array}{l}91 \\
(11) \\
(n=16)\end{array}$ \\
\hline $\begin{array}{l}\text { Embryo mortali- } \\
\text { ties at full- } \\
\text { term of set (\%) }\end{array}$ & $\begin{array}{l}3 \\
(3) \\
(n=16)\end{array}$ & $\begin{array}{l}3 \\
(3) \\
(\mathrm{n}=15)\end{array}$ & $\begin{array}{c}1 \\
(1) \\
(n=15)\end{array}$ & $\begin{array}{c}1 \\
(2) \\
(\mathrm{n}=16)\end{array}$ \\
\hline $\begin{array}{l}\text { Pipped not liber- } \\
\text { ated of set }(\%)\end{array}$ & $\begin{array}{l}6 \\
(6) \\
(n=16)\end{array}$ & $\begin{array}{l}5 \\
(4) \\
(n=15)\end{array}$ & $\begin{array}{l}7 \\
(5) \\
(n=15)\end{array}$ & $\begin{array}{l}4 \\
(5) \\
(n=16)\end{array}$ \\
\hline $\begin{array}{l}\text { Day-14 survivors } \\
\text { of set (\%) }\end{array}$ & $\begin{array}{l}71 \\
(16) \\
(n=16)\end{array}$ & $\begin{array}{l}72 \\
(10) \\
(n=15)\end{array}$ & $\begin{array}{l}68 \\
(23) \\
(n=15)\end{array}$ & $\begin{array}{l}74 \\
(13) \\
(n=16)\end{array}$ \\
\hline $\begin{array}{l}\text { Normal } \\
\text { hatchlings of } \\
\text { day-17 live } \\
\text { embryos ( } \% \text { ) }\end{array}$ & $\begin{array}{l}90 \\
(10) \\
(n=16)\end{array}$ & $\begin{array}{l}92 \\
(5) \\
(n=15)\end{array}$ & $\begin{array}{l}92 \\
(5) \\
(n=15)\end{array}$ & $\begin{array}{l}94 \\
(6) \\
(n=16)\end{array}$ \\
\hline $\begin{array}{l}\text { Day-14 survivors } \\
\text { of nomal } \\
\text { hatchlings (\%) }\end{array}$ & $\begin{array}{l}87 \\
(10) \\
(n=16)\end{array}$ & $\begin{array}{l}89 \\
(8) \\
(0=15)\end{array}$ & $\begin{array}{l}80 \\
(26) \\
(1=15)\end{array}$ & $\begin{array}{l}86 \\
(8) \\
(n=16)\end{array}$ \\
\hline
\end{tabular}

4 There were no significant differences from the control $(p<0.05)$ using a Dunnett's one-tailed test.

ated with accidental injuries or deaths. Specifically, these were: (1) three chicks hatched from control diet-fed adults, seven chicks hatched from $279.2 \mu \mathrm{g} / \mathrm{g}$-fed quail, and one chick hatched from $1,113.6 \mu \mathrm{g} / \mathrm{g}$-fed quail had excoriation; (2) two offspring of control diet-fed quail, two offspring of 279.2 $\mu \mathrm{g} / \mathrm{g}-\mathrm{fed}$ quail, and one offspring of $557.4 \mu \mathrm{g} / \mathrm{g}$-fed quail were found dead in the feeder apparatus; (3) one chick from control diet-fed adults and two chicks from $557.4 \mu \mathrm{g} / \mathrm{g}$-fed adults died or were euthanized due to broken legs; (4) a chick hatched to $557.4 \mu \mathrm{g} / \mathrm{g}$-fed quail showed lethargy and within a day a dead chick was found in this hatch; and (5) two chicks from the $1,113.6 \mu \mathrm{g} / \mathrm{g}$-fed quail were lethargic and had excessive amounts of eye matter.

Gross pathology examinations of chicks euthanized or found dead during the strychnine-diet period confirmed that three offspring of control diet-fed and one chick from $279.2 \mu \mathrm{g} / \mathrm{g}-\mathrm{fed}$ adult quail had excoriation of the feet, and three from the 557.4 $\mu g / g$-fed adults had a red, gel-like fluid on the top of their beaks. No pathology occurred for chicks euthanized after the 14-day post-hatch periods.

\section{Discussion}

The no observed adverse effect levels (NOAELs) for subchronic strychnine-diet exposures on reproduction in mallard ducks and bobwhite quail were 33.2 and $1,113.6 \mu \mathrm{g} / \mathrm{g}$ strychnine alkaloid, respectively. Thus, at current dietary concentrations, the null hypothesis (i.e., subchronic ingestion of strychnine would not impact reproduction) was rejected for mallards, but not rejected for bobwhites. Reproductive effects in mallards occurred at roughly a 34 -fold less dosage that for quail. These data are in agreement with the acute data published by Stemer et al. (1998), which showed the gallinaceous species to be 10-fold less sensitive than the waterfowl species to 28-day, subchronic effects. The NOECs in Sterner et al. (1998) were $972.6( \pm 54.0)$ and $91.1( \pm 27.3) \mu \mathrm{g} / \mathrm{g}$ strychnine, respectively. Prior acute oral toxicity ( $\left(D_{50}\right)$ studies involving galliformes and anseriformes dosed with strychnine have reported $\mathrm{LD}_{50}$ values of $27 \mathrm{mg} / \mathrm{kg}$ for ring-necked pheasant (Phaisiamus colchicus), $35-50 \mathrm{mg} / \mathrm{kg}$ for sage grouse (Centrocercus urophasianus), $50 \mathrm{mg} / \mathrm{kg}$ for turkey (Meleagris gallopavo), and $112-161 \mathrm{mg} / \mathrm{kg}$ for California quai] (C. califomica) versus $2.27-5.88 \mathrm{mg} / \mathrm{kg}$ for mallard ducks (Hudson et al. 1984; USDA 1994).

Analyses of strychnine diet samples showed that the uniformity of mixes across monthly periods of the live-bird studies was acceptable. Mean strychnine concentrations for mallard duck diets were $94.8,98.4$, and $100.6 \%$ of the intended 35,70 , and $140 \mu \mathrm{g} / \mathrm{g}$ values; average concentrations formulated into bobwhite quail diets were $93.0,92.9$, and $92.8 \%$ of the intended 300,600 , and $1,200 \mu \mathrm{g} / \mathrm{g}$ strychnine quantities. In the absence of a published formulation criterion for live-bird reproductive studies (see American Society for Testing and Materials 1991; Bennett and Ganio 1991; US EPA 1982, 1986), the batch-tobatch variation was relatively minor and was judged to be of minimal biological significance to assessments of the reproductive toxicological endpoints in either the duck or quail studies. Obviously, the dietary concentrations chosen for bobwhite quail should have been elevated to induce toxicity in at least one group of quail (US EPA 1982, 1986), but results are still informative.

Despite the use of numerous foxicity endpoints, relatively few variables yielded statistically significant reproduction effects for mallards. Essentially, dietary intake of strychnine by 
the $F_{0}$ generation ducks was associated with the following: (1) neurological signs in seven adults fed $\geq 68.9$ mean $\mu \mathrm{g} / \mathrm{g}$ diet; (2) decreased body weights in adult females by week 20 of dietary exposure to $140.9 \mu \mathrm{g} / \mathrm{g}$ strychnine; (3) a few postmortem pathologies (i.e., small testes, pale liver, and enlarged intestinai vessels in single ducks each fed each test diet, respectively) that were unlikely to have been diet-induced; and (4) decreased egg production for hens fed $140.9 \mu \mathrm{g} / \mathrm{g}$ strychnine. Effects in $F_{1}$ generation ducklings were: (1) lower hatching body weights (relative to control offspring) if hatched from eggs of adults fed 68.9 or $140.9 \mu \mathrm{g} / \mathrm{g}$ strychnine in both the strychnine-diet and recovery periods; (2) a few cases of clinical signs (i.e., two ducklings from $68.9 \mu \mathrm{g} / \mathrm{g}$-fed ducks displayed lethargy and/or nonambulation, which were unlikely signs to have been strychnine-induced): (3) decreased 14-day survivability (telative to control offspring) for ducklings in the recovery period when hatched from eggs of adults fed $140.9 \mu \mathrm{g} / \mathrm{g}$ strychnine diets; and (4) some gross pathologies on sacrifice (i.e, one, five, and four ducklings from control, 33.2, and $68.9 \mathrm{~kg} / \mathrm{g}$ strychnine-fed adults displayed some liver pathologies) that were counter to expectations and unlikely to have been strychnine-induced.

Our results imply that physiologicalanatomical differences of these nontarget species influence strychnine's mode of action. Although derivation of a possible mechanism of action that could cause these diverse, limited effects is difficult, we believe that it is largely nutritional, rather than teratogenic (i.e., no eggshell-thinning or embryo-viability effects were observed). The adult hens were severely stressed during egg production; $45-\mathrm{kg}$ baiches of diets were needed for the mallards after week 13 to meet ad libifum consumption demands during the egg-laying phase. Although the diet was protein-laden and no decreased consumption effects were significant, the loss of weight by hens fed $140.9 \mu \mathrm{g} / \mathrm{g}$ strychnine suggests that the multiweek period of egg production may have produced borderline nutritional stress and could have impacted egg nutrients. This would account for both the decreased body weights of respective ducklings and their poor survivability.

Toxicity or reproductive risks posed to either galliformes or anseriformes, by currently registered applications of strychnine, are practically nil. Essentially, two bait forms are produced (i.e., $0.5 \%$ milo and $0.5 \%$ steatn-tolled oats). These registrations limit strychnine use to below ground, burrow applications for the control of pocket gophers (Thomomys/Geomomys sp.)-a strategy intended to mitigate nontarget exposures (Federal Register 1983). Although it could be argued that mitigation of exposure would be more important near wetlands (ducks) than in upland watersheds (quail) or that an accidental spill of poisoned bait could occur, the potential for foraging wild ducks or quail to ingest an acute dose, let alone a more slowly acquired subchronic or chronic dose, of the chemical under current use restrictions seems remote.

Acknowledgments. Research was funded by The Strychnine Consortium-a group of private distributors/producers and govemment users of the pesticide. We thank the consortium for permission to publish these data. Connie Lesar and Darlene DuCharme performed many of the routine data collections in the live-bird portions of the studies; Carol Furcolow developed and validated the analytical method used for strychnine determinations (Method 25A); Rori Craver provided periodic chemical analyses of the technical product; Dave Goldade and
Steve Greiner performed the monthly analyses of strychnine diets; and Kathleen Fagerstone and John Eisemann, plus two anonymous reviewers for AECT, provided helpful critiques of the manuscript.

\section{References}

American Society for Testing and Materials (1991) Standard practice for conducting reproductive studies with avian species, vol. 11.04, E 1062-86 (Reapproved). American Society for Testing and Materials, Philadelphia, PA, pp 706-716

Bennett RS, Ganio LM (1991) Overview of methods for evaluating effects of pesticides on reproduction in birds. EPA 600/3-91/048, Environmental Protection Agency, Office of Research and Development, Environmental Research Laboratory, Corvallis, OR, $106 \mathrm{pp}$

Brown VK (1988) Acute and sub-acute toxicology. Edward Annold, London, UK, pp 1-6

Buck WB (1991) Toxicity of pesticides in livestock. In: Pinnental D (ed) CRC handbook of pest management in agriculture, vol. II. CRC PTess, Boca Raton, FL, Pp 571-587

Colvin BA, Hegdal PL, Jackson WB (1988) Review of non-target hazards associated with rodenticide use in the USA, EPPO Bull $18: 301-308$

Duncan DB (1955) Multiple range and multiple F tests. Biometrics $11: 1-42$

Dunnett CW (1955) A multiple comparison procedure for comparing several treatments with a control. I Am Stat Assoc 50:1096-1121

Federal Register (1983) Intent to cancel registrations of pesticide products containing strychnine 48 (203). Wednesday, Oct. 19, US Government Printing Office, Washington, DC, p 48522

Furcolow C (1990) Strychnine bird feed assay-Purina game bird breeder Layena ${ }^{\text {si }}$. Analytical Method 25A, USDA/APHIS/ADC, Denver Wildlife Research Center, Analytical Chemistry Report, Denver, $\mathrm{CO}, 10 \mathrm{pp}$

Grałz NG (1973) A critical review of currently used single-dose rodenticides. Bull Wrld Hlth Org 48:469-477

Hollander M, Wolfe DA (1973) Nonparametric statistical methods. John Wiley \& Sons, New York, NY, pp 68-75

Hudson RH, Tucker RK, Haegele MA (1984) Handbook of toxicity of pesticides to wildlife, 2nd ed. Resource Publ. 153, US Department of the Interior, Fish and Wildlife Service, Washington, DC, $90 \mathrm{pp}$

Levene H (1960) Robust tests for equality of variances. In: Olkin I, Hoeffding W, Churye SG, Madow WG, Mana HB (eds) Contributions to probability and statistics. Stanford University Press, Stanford, CA, pp 278-292

Merck Index: an encyclopedia of chemicals, drugs, and biologicals, 12th ed. (1996) Merck Research Laboratories: Whitehouse Station, $\mathrm{NJ}$, pp 9016-9017

Murphy SD (1986) Toxic effects of pesticides. In: Casarett and Doull's toxicology: the basic science of poisons, 3d ed. Macmillan Publishing Co., New York, NY, p 566

Ramey CA, Schafer EW Jr, Fagerstone KA, Palmateer SD (1994)Active ingredients in APHIS's vertebrate pesticides-use and reregistration status. Proc Vertebt Pest Conf 16:124-132

SAS Institute (1989) PROC ANOVA. It: Parker JC (ed) SAS/STAT ${ }^{\text {g }}$ guide for personal computers (version 6), fourth edition, vol. 2. SAS Institute Inc., Cary, NC, pp 209-244, 1325-1350

Stemer RT, Pedersen CA, Helsten BR, Goodall MJ (1998) Subchronic dietary toxicity of strychnine: bobwhite quail are less sensitive than mallard ducks. Arch Environ Contam Toxicol 35:498-505

USDA, Animal Plant and Health Inspection Service, Animal Damage Control Program (1994) Final Environmental Impact Statement, vol 3 (appendix P). US Department of Agriculture, Animal Plant and Health Inspection Service, Washington, DC, pp 78-80

US EPA (1982) Pesticide assessment guidelines, subdivision $E_{\text {, hazard }}$ evaluation: wildlife and aquatic organisms. PB83-153908, EPA-540/ 
9-82-024, US Environmental Protection Agency, US Government Printing Office, Washington, DC, $86 \mathrm{pp}$

US EPA (1986) Hazard evaluation division standard evaluation procedure-avian reproduction test. PB87-209177, EPA-540/9-86-139,
US Environmental Protection Agency, US Government Printing Office, Washington, $\mathrm{DC}, 13 \mathrm{pp}$

Winer BJ (1971) Statistical principles in experimental design, $2 \mathrm{~d}$ ed. McGraw Hill, New York, NY, pp 149-305, 559-571 